\title{
Valter Milovan \\ FRANCI BLAŠKOVIĆ I GORI USSI WINNETOU - "ZVUK ISTRE KROZ BESIDU"
}

\author{
Pregledni rad \\ Review article
}

UDK 811.163.42'282.2(497.5-3 Istra):784.4/.72

\begin{abstract}
Franci Blašković je s grupom Gori Ussi Winnetou od njezina nastanka 1986. godine do 2008. snimio 59 glazbenih albuma, promijenio mnogo suradnika, tekstopisaca i glazbenika te se okušao u mnogo glazbenih stilova da bi 2008. raspustio grupu. Uz kratak povijesni prikaz, u radu je iznesen pregled sastavnih elemenata tog povelikog korpusa; jezične značajke (besidarenje, jezične interferecije, višejezičnost i dijalektalnost, utjecaj talijanske pjesmarice, frazemi) te tematika (povijesne teme i kritika društveno-političkog sistema) pjesama grupe.
\end{abstract}

Ključne riječi: dijalektalna poezija, jezična interferencija, rock and roll, povijest Pule

\section{Uvod}

O glazbenom sastavu Gori Ussi Winnetou i njegovu specifičnom postojanju u sklopu hrvatske (ranije jugoslavenske) rock glazbe i kulture pisano je relativno malo: novinski intervjui i glazbene recenzije glavna su građa u kojoj se možemo približiti tom svijetu, uz prigodne predgovore (njihovim) knjigama te nekoliko enciklopedijskih članaka. Znanstvenim su diskurzom o njima progovorile Irena Marković1 te Mirjana Benjak i Vesna Požgaj Hadži koje su u tekstu Od multikulturalizma k interkulturalizmu² pjesmu Patrizia Daniela Načinovića (odnosno winnetouovsku Addio Pola) iskoristile kao metodički (didaktički) model.

Grupu su sa svijetom književnosti i pitanjima jezika povezivale suradnje s pjesnicima (Načinović, Drago Orlić, Milan Rakovac, Budimir i Bojan Žižović, Loredana Bogliun Debeljuh, Tahir Mujičić i drugi), a dokaz njihove izvođačke širine i kvalitete su i nastupi u sklopu književnih večeri ili u sklopu umjetničkih performansa.

U ovom ćemo radu, prigodno i obljetničarski, pokušati izdvojiti najvažnije značajke rada te osebujne grupe. Kroz dvadeset dvije godine rada prepoznaju se različite faze i karakteristike u radu grupe. O svakoj od njih reći ćemo nekoliko riječi te ih pokušati potkrijepiti kroz stihove pjesama grupe ili izvacima iz Blaškovićevih intervjua. To su jezične značajke (besidarenje, citati iz povijesti rocka, utjecaj talijanske pjesmarice, jezične interferecije, višejezičnost i dijalektalnost, frazeologija) te tematske odrednice (povijesne i političke teme, kritika sistema, antikapitalizam i antiklerikalizam).

\footnotetext{
Marković, Irena, // code-switching tra istroveneto e cicacavo istriano nei testi di Franci Blašković, Atti del XVII Congresso A.I.P.I., Asoli Piceno 2006.

2 Benjak, Mirjana, Pozgaj Hadži, Vesna, Od multikulturalizma ka interkulturalizmu, Zbornik radova (Knjiga 1), Peti međunarodni interdisciplinarni simpozijum Susret kultura, Novi Sad, 2010, str. 163-172.
} 


\section{Povijest grupe}

Prošlo je dvadeset i pet godina otkako je u sklopu projekta Beesida eli sida, u proljeće 1986. godine, nastala grupa Gori Ussi Winnetou. Najuočljivije značajke tog glazbenog sastava bile su neformalnost i opuštenost izraza te pjevanje o istarskim socijalnim i povijesnim temama. lako je u osamdesetim godinama dvadesetog stoljeća u Istri djelovalo već afirmirano Atomsko sklonište, a svoj su status strpljivo gradili pankeri KUD Idijoti, Gori Ussi Winnetou su u tim godinama postali gotovo sinonim za rock and roll na istarski način. Grupa je, naime, bila poznata po (tako su pisali na plakatima) ossteria tourssima, tj. turnejama po istarskim oštarijama u kojima su "pronosili luč" rock and rolla inficiranog čakavštinom, često u prostorima do kojih takav glazbeni izraz nije nikad prije ni stigao. I dok se istarski i pulski milje manje prepoznavao u pjesmama gore spomenutih izvođača, Gori Ussi je ostajao tvrdokorno lokalan s tekstovima koji se često tiču samo određenog kvarta, mjesta, vremena ili supkulturne zajednice te s izraženim interesom za jezik i jezike (čakavica i istromletački uz dodatak talijanskih, engleskih, njemačkih, srpskih, slovenskih i drugih izraza te hrvatskog i talijanskog standarda). Dolazimo tako do zaključka da je jedno od ključnih pitanja grupe Gori Ussi Winnetou pitanje identiteta na kojem grupa inzistira i postiže više od ranije spomenutih (kvalitetnih) kolega rokera. Na tom će se identitetu i njegovoj afirmaciji kasnije graditi predstavnici Ča-vala (Gustafi, Alen Vitasović, Livio Morosin, Šajeta, duo Battifiaca i dr.) u devedesetim godinama, jednako kao i stranka IDS³.

Gotovo jedini stalni član benda bio je vokal i basist Franci (pravo ime Franko) Blašković. Uz njega je na prvih desetak albuma također potpisana supruga i koautorica Arinka Šegando, s kojom je Blašković već nastupao u grupi Arinka i Ting/ Tangl, a koja je snimila dva albuma i nekoliko singlica. ${ }^{4}$

Prvi album grupe Addio Pola objavili su 1986. za Suzy, a posljednji pedeset deveti album Od A - do Я, krajem 2008. godine kao samizdat, nakon čega Blašković raspušta grupu i snima pod drugim imenima. ${ }^{5}$ Jedna od prekretnica u Blaškovićevu radu bilo je ponovno objavljivanje prvih sedam albuma pod egidom Sabrana dela 2001. godine. Nakon suradnje s FAK-ovcima i objavljivanja etno-punk albuma Etnocid iz 2003. i četiri albuma u 2004. godini, Blašković kreće u mahnito objavljivanje albuma jednom mjesečno uz različite rezultate, od ispraznih do jako dobrih, ovisno o situaciji ili tekstualnom predlošku koji je imao pred sobom. Prorjeđuju se nastupi i Ossteria toursi, nekoliko je puta (originalno) odradio čitavu turneju u jednom danu6 da bi zatim prestao is time, svodeći tako besidarenje samo na objelodanjivanje albuma (nije se moglo govoriti ni o "izdavanju" jer dugo nije postojao zainteresirani izdavač) i bez nastupa.

\footnotetext{
3 "I Nino Jakovčić i Damir Kajin i svi oni bili su moja publika. I dok sam ja lajao na koncertima, oni nisu od straha to imali snage ni slušati, da bi poslije isti ti ljudi dokapitalizirali tu utopističku ideju Istre. Ali tu moramo krenuti od početka. To je zavičajni sindrom Istre, taj osjećaj i želja za čistom situacijom, u kojoj nemaš jebenu pripadnost vjeri, naciji, jeziku, koja bi te obvezivala na bilo što.", iz intervjua Nacionalu, br. 371, 24. 12. 2002.

4 Diskografija Tingl Tangla - albumi: Na stanici za bus (PGP RTB 1981), Tražim nekog srca mekog (Diskoton, 1981). Singlovi: Doktor me laže/lstarski rok, (PGP RTB 1976), Bla bla bla/Ima šanse-nema šanse (PGP RTB 1979), Naš dida berekin/Sivi sokole (1980), Da sam lijepa i seksi/Jedinstvena nedjelja u Montezaru (PGP RTB 1980.), Sivi sokole/Partizanka (Diskoton). Pjesme s festivala: Bla bla bla (Split 79), Ima šanse, nema šanse (Melodije leta 1979.). lako je ponegdje potpisana zajedno s Ting Tang/om, Arinka je samostalno snimila album Novi rulet (Diskoton 1982.).

5 Nakon raspuštanja Gori Ussi Winnetoua, Blašković mijenja imena prema potrebi: Fonja Big Band, Rostiglio, Francivurijan, Nja Nja Mirko fra Slavko, Bankrot O'Franz.

6 Primjer jednodnevne turneje iz veljače 2008.: Pula u 11:55, Valbandon 12:45, Vodnjan 13:30, Krnica 14:15 i tako po Istri sve do spomenika Giuseppini Martinuzzi u Labinu oko 21:30 i kluba Palach u Rijeci u kasnim večernjim satima.
} 


\section{Jezične značajke 3.1. Besidarenje}

lako i sam dobar pjesnik, Franci Blašković često nije autor tekstova koje izvode Gori Ussi Winnetou. Blašković se kroz godine afirmirao kao izvođač tuđih pjesama, koji bira i s lakoćom posvaja stihove npr. Drage Orlića ili Predraga Lucića, te kao umjetnik kojem je performans najbitniji i koji se upravo u tom dijelu svojeg umjetničkog izričaja najviše daje. Negdje u razgovoru s Blaškovićem postaje jasno kako on živi za performans, često s velikim osjećajem odgovornosti i obveze prema (svojim i tuđim) tekstovima koje je odlučio uglazbiti. Od drugih aktivnosti, kao što su izdavanje ili pojavljivanje u medijima, Blašković, čini se, zazire i obično igra ulogu buntovnika ili to stvarno i jest. Bitan je dakle performans, ossteria tour kojim je godinama obilazio Istru, bitan je koncert, bitne su pjesme gotovo u istoj mjeri u kojoj i priče između njih. Blašković svoju umjetničku aktivnost naziva besidarenjem:

Ma ke karijera? Baš suprotno. Mi nikad nismo htjeli nikakvu karijeru i sve smo radili da nemamo nikakvu karijeru, niti su to bili koncerti. To bih prije nazvao besidarenjem. A krenuli smo prije šesnaest godina iz gostionice "Lipi i grdi" u Kanfanaru, točno u podne za Vazam. I od tada sviramo samo po gostionicama. To što smo u samom početku najprije uspjeli u Zagrebu, pa tek onda u Istri, trebalo nam je zato jer su nam tada doma govorili da je to što radimo štupido. Kao, kakav istrijanski rock, tko je to vidio. E, tek kad su nas prihvatili u Zagrebu, vratili smo se doma da bismo mogli zajebati ove naše i pokazati im da je naša glazba dobra.?

Ti moj besidarij i konzumacija tega ča je bilo na bini imala je nazovi zvuk Istre kroz besidu. Ona ni imala nikakav smišljeni, nanke politički bilo ke vrste, niš. Jedino ča ja kroz govorenje, normalno, vajk bilo da san ja konzumira ti svoj jezik. Koji je, moreš reći, Istra. ${ }^{8}$

Požalio se ipak kako mu je ideja Istre kao neideologije, odnosno poistovjećivanje vlastite stvarnosti s jezikom (dijalektom) koji govori, oteta u političke svrhe (IDS), što ga je postupno razočaralo i ogorčilo.

Ma najiritantnije je uvijek postaviti pitanje radi čega ti to radiš? Radiš uvijek nešto što zadovoljava tvoju projekciju življenja. Samo u mojem slučaju nije bilo političkih namjera, ni namjere osnivanja stranke, partije, saziva. Jedina namjera bila je iskazati svoje osjećaje. Upravo to smatram početkom nečega što je organiziralo misao kod ovih politički spretnijih tipova. (...) Ma ja sve njih, na žalost, poznajem. Oni su dolazili i na moje koncerte, oni su moju glazbu i slušali i pjevali. Oni su mi čak bili i sponzori, oh yeah! Puno današnjih članova IDS-a su mlađi ljudi koji u to vrijeme i nisu zalazili u gostionice jer in nije zanimao taj milje, a osim toga ja sam tamo izvodio ono što nikad prije nije pripadalo u gostionicu, a tad se u Istri točno znalo što se u oštariji može, a što ne. Ben! Sad se u Istri u gostionici može sve, a moram priznati da sam bio pionir. Prvi sam svojim besidarenjem poremetio te prostore konzumacije. No, dakle, u vrijeme kad su oni osnovali IDS već su ideja i program bili formirani kroz moje ispade u gostionicama. Osim toga, sve ono što je njima bilo nezgodno reći i što in je bilo strah, nakon što sam ja to već negdje izlajao, oni su se mogli pozvati na mene. Dakle, imali su feedback. Hoću reći da sam ja verbalizirao ideju, a oni su pokrenuli partiju i imali su u tome sve do nedavno moju nesebičnu podršku, iako nikad nisam bio član ni jedne partije, ni stranke, pa tako ni IDS-a. ${ }^{9}$

$7 \quad$ Nacional br. 371, 24. 12. 2002.

8 Orlić, Ivona: Suvremeni istarski identitet: Besidarenje Francija Blaškovića i njegov doprinos konstrukciji identiteta Istrijana, neobjavljeni magistarski rukopis, str. 146.

9 Nacional br. 371, 24. 12. 2002. 
Blaškovićevo besidarenje, iako (kako kaže) primarno osobni izbor i čin, jednom ponuđeno publici poprimilo je elemente propovjedi i provokacije, iščitano je i kao poziv na buđenje onog sloja ljudi koji je ostao zagušen i prekriven prvo jugoslavizacijom pa onda pretjeranim domoljubljem, socijalizmom pa kapitalizmom te općenito bezumljem i ne-vrijednostima koje se promoviraju na televiziji. No, slobodoljubivost i anarhičnost imaju i svoju cijenu. Tako stihovi poput:

Jedan je dobrotvor sebi naša žrtvu

I reka nije loše činiti dobro

inquisitore pasinese

fa la cagada più volte al mese $e^{10}$

nisu mogli naći put do županijskog radija jer se netko prepoznao u njegovim stihovima.

\subsection{Talijanska pjesmarica}

Talijanske su zabavne i narodne pjesme činile (čine to i danas), uz hrvatski, dio kulturnog blaga Istre. Pripadaju raznim razdobljima: neke su narodne i stare (npr. Ancora un litro de quel bon), druge su ušle u pamćenje za talijanske vladavine (npr. Piemontesina je iz 1939.), treće u drugoj polovici 20. stoljeća (npr. Marina) kao hitovi sa Sanrema ili talijanskog radija. Ljudi ih poznaju, slušaju i pjevaju. U svojim se tekstovima Blašković i još neki njegovi autori (Orlić, Rakovac) pozivaju na taj kulturni element te spominju njihove stihove ili naslove u svojim stihovima, često mijenjajući njihov smisao s humornim ili ironijskim rezultatima. Tako pjesma Carla Butija Torna piccina mia (Vrati se, malena moja) u imitaciji govora pulskih Talijana (tj. na iskrivljenom hrvatskom) postaje:

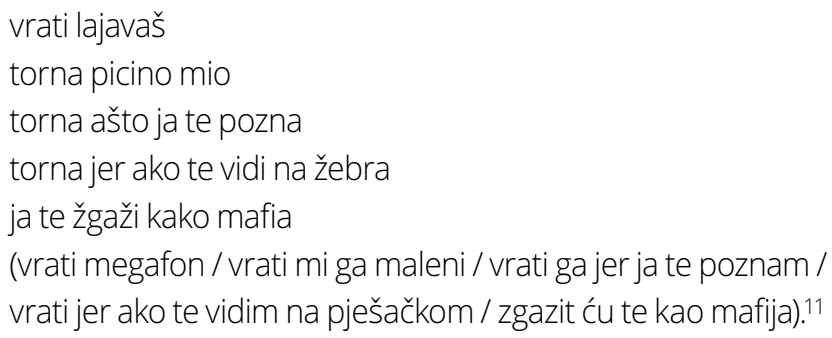

Isto tako, iako tekst ostaje isti, mijenja se karakter pjesme - tako narodna pjesma Che bele gambe la ga la mula jole postaje slow rock:

Ke bele gambe da gavaš

Jole

sunce ti je je je o je

udušija san te u sebe jušto vode

(...)

joh joh Jole ča vraga čekaš vrime gre

e bella sei e bella sempre resterai12

Citirana je tako i talijanska stara himna (Va pensiero, fanculo, va), Da Trieste fino a Zara, La famiglia dei Gobbi, Marina (Rocco Granata, hit iz 1959.), Ti col mus, mi col tram (Andemo a Servola), Mamma dammi cento lire i mnoge druge. Samo na prvih desetak albuma možemo nabrojati bar dvadeset preuzimanja-citata iz talijanskih pjesama, ne brojeći talijanske brojalice, reklamne jingleove,

10 Pjesma Turbo cattolido, peste balcanica, album Istra ti materina, 1995

11 Pjesma Kumpanjo Giovanni Glembajević be good, album Addio Pola, 1986.

12 Pjesma La mula Jole, album Addio Pola, 1986. 
izreke, poslovice ili pak socijalističke borbene pjesme13 koje ćemo ostaviti za neku drugu priliku. Kasnije se, mijenjajući tekstopisce, mijenja i jezik na kojem Blašković pjeva (ima sve više pjesama na pulskom gradskom štokavskom govoru) pa je citata iz talijanskih pjesama manje, ali talijanski živi kao sastavni dio izvedbe do kraja rada sastava kao i u albumima koje je izdao nakon toga.

\subsection{Citati iz povijesti rocka}

Citatnost grupe Gori Ussi Winnetou vidljiva je i iz jedne druge tradicije: Blašković, ex-basist grupa Sateliti i Ting/ Tang/, unio je (u vlastite tekstove) niz citata ili naslova pjesama iz povijesti rock i pop glazbe. Nalazimo tako Life is Life austrijske grupe Opus, The Fool on the Hill i Across the Universe Beatlesa, Satisfaction Rolling Stonesa, Tarzan Boys prema istoimenom italo-disco hitu grupe Baltimora i mnoge druge. I u ovom je slučaju očit ironijski odmak i posvajanje naslova u svojoj izvrnutoj logici - tako Wild Boys postaju Wa boys ("bua dečki"), Johnny iz pjesme Chucka Berryja postaje Giovanni Glembajević Be Good, a opisujući dolazak novog vremena i nove vladajuće strukture u Pulu nakon 2. svjetskog rata, Blašković in naziva Rolling stronz's (u slobodnom prijevodu: kotrljajuća govna). Rock Me Baby postaje Roč me bebe, a Let's Twist Again, stari hit Chubbyja Checkera, postaje borbeni poklič koji će Blašković uzvikivati prije gitarskih sola na pjesmama. U pjesmi Idioti spominju se njegovi stari drugovi KUD Idijoti s kojima se u istom terminu našao u Zagrebu, a u pjesmi Chi non pissa in compagnia (još jedna narodna izreka) smije se Atomskom skloništu i njihovoj pjesmi Pomorac sam majko u jednom disku u Nedešćini:

Scoionamento totale i soliti cretini cagaju

z škurine minut do militara a cila sala kanta Pomorac sam majko

U istoj pjesmi koja opisuje događaje u tom disku i miješanje domaćih, fureštih i turista radio peva na sav glas zumba zumba bakalar i hajd zapevaj s nama ti trajna nina nena... Blašković zaključuje kako optimizam nema smisla:

l'assurdita dell'ottimismo previše munjenih je u điru me fa paura sta gente col suo crno-beli svet u ritmu marčete za voza nikako da činiš puk. ${ }^{14}$

\subsection{Sintagme i frazeologija - poetska ekonomičnost}

Stilska razbarušenost i "opuštenost" u tekstovima grupe pogoduje upotrebi mnogih frazema i sintagmi, mnogo više nego što bi to bilo moguće u standardnoj pop ili rock pjesmi ili u mnogoj poeziji. Sintagme se koriste (najčešće u tekstovima čiji je autor sam Blašković) bilo zato da se postigne humoristični efekt bilo u stilske svrhe ili da postigne sažetost u komunikaciji. Pronalazimo tako primjerice:

1) kolokvijalne frazeme i narodne izreke poput npr:

Gira canton pasa pasion, iz pjesme Điđi Anarhišta, u kojoj protagonist pjesme u jednom stihu baca bombu Mussoliniju pod noge (samo ča ni škopjala) i pleše valcer z Duncan Izodoron u Luganu, a u sljedećem mora bježati zbog međunarodne reahcije. Tako brzi prijelaz postignut je upravo tom talijanskom izrekom ("skreneš iza ugla, prođe te strast"), to jest kolokvijalnim frazemom. Slično tome, u dva stiha opisuje se nova vlast u Istri:

\footnotetext{
13 Poput talijanskih pjesama, u tekstovima grupe nalazimo pjesme/stihove: Po šumama i gorama, Bandiera rossa, Lupog/av Štalije to je naša meta, Amerike i Engleske bit će zemlje proleterske, Nije Tito koji hoće Istru većje Istra koja hoće Tita, Druže Tito ljubičice bijela, U boj, u boj junaci, istarsku himnu Krasna zemljo i dr.

14 Pjesma Chi non pissa in compagnia, album Welcome Home, 1989.
} 
Cosa nostra, cosa vostra,

casa nostra, cosa vostra15

u kojem naša kuća u dodiru s određenom mafijom i dolaskom određenih povijesnih prilika postaje njihova stvar. Također, homofonija cosa-koza može značiti i prelazak Istre u ruke drugog "vlasnika". Sve je to izgovoreno na talijanskom pa se tako poruka i čuva od razumijevanja onih koji ne znaju jezik i od eventualne cenzure. U opisima likova kolokvijalni frazemi također služe poetskoj ekonomičnosti - tako se u jednom retku Dobar čovik super hik opisuje pijanac koji je ujedno dobar čovjek ili u Razumiš ti capisci je sudao sette camicie opet na iskrivljenom čakavskohrvatsko-talijanskom osobu koja se puno namučila (sudare sette camicie, oznojiti sedam košulja je fraza koja znači puno raditi da bi se nešto postiglo).

2) Žargonski frazemi pripadaju ponajviše svijetu televizije i rock glazbe. Tako Born to be Wild (Steppenwolf) ili Born to Lose (Heartbreakers, Sid Vicious) postaje Born to be BU a Scolio Iivi, odnosno "rođen da radiš u Brodogradilištu Uljanik", što je bliže osjećaju gubitka nego osjećaju neukrotivosti i divljine. Slično Easy rider augmentira svoje značenje, odnosno postaje dvostruko spor u sintagmi Easy rider con la fjaka. Zabavan je i frazeološki kalk u netočnom prijevodu step by step, passo by pass (korak po korak), kao i me fa paura sta gente col suo crno-beli svet.

3) Knjiški frazemi su, zanimljivo, uglavnom na latinskom jeziku. Ponovno je prisutno izvrtanje njihovog stvarnog značenja. Tako stari rimski naziv za Mediteran Mare nostrum u pjesmi Pola città puttana počinje značiti Jadransko more ili samo Pulski zaljev, koji više nije naš, već je, kao što zna svatko tko je turistički posjetio grad ili služio u Puli vojni rok prije devedesetih (a mnogo je takvih), podređen potrebama vojske i brodogradilišta:

oj more dimboko

mare nostrum un bel cazzo nostrum

velika hiža ud vojske na obali

(...)

oj kalebi more modro škuro

balli dei oficiai della marina

casa della marina

sve della marina, marina, marina, marina16

Poslovica Mens sana in corpore sano (rimskog pjesnika Juvenala iz prvog stoljeća poslije Krista), postaje tako Mens sana in malvasia istriana, a Cezarova Galia est pacata (također iz prvog stoljeća) postaje Histria (š)pakata est devetnaest stoljeća kasnije, u vremenu kad se Hrvatska osamostaljuje pa se na teritoriju Istre pojavljuje i druga, hrvatsko-slovenska granica.

Upotreba i igra s frazemima u pisanju i interpretaciji Francija Blaškovića

1. ubrzava ritam pjesme (Gira canton)

2. od frazema čini zaključak pjesme ako je u pitanju neka narodna mudrost (ili samo mudrolija) pa onda i naslov (Mens sana)

3. daje pjesmi neočakivane zaplete bilo tekstualno bilo glazbeno (Marina, Rocco Granata)

4. služi se u karakterizaciji likova koji su tako opisani samo jednim stihom (Dobar čovik super hik, je sudao sette camicie)

5. poput metafore, metonimije, sinestezije ili drugih pjesničkih slika, frazemi sudjeluju u "zgušnjavanju" jezika. 


\subsection{Višejezičnost i dijalektalnost. Jezična interferecija}

Jezici kojima se Blašković i njegovi suradnici koriste u svojim tekstovima već su nabrojani u uvodu. Možemo samo dodati kako je, nakon četrdeset pet godina Jugoslavije i dvadeset hrvatske samostalnosti, sličan izričaj prije stilističke negoli sociolingvističke prirode prisutan i kod djece koja pohađaju talijanske škole (bilo je i istraživanja na tu temu17) kao i kod odraslih talijanskih govornika u nekom šaljivom kontekstu (npr. "andemo a comprar i smoki e i štapicí", "ela la ga speso tuti i soldi e nikom ništa", "maledetti Ki-Ki, ma su dobri"). Stilski učinak višejezičnosti i kontaminacija u pjesmama grupe ima sljedeće učinke:

1. karakterizacija likova - npr. ljuta Puležanka prijeti: ara che te dago uno col giornal, sa!, dvije stare usidjelice plešu po podau am schonen blauen donau;

2. humornost - muž koji se ispričava ženi: znaš draga, anke Afrika je u kurcu z svin bananami ča su ma zovi Šiftara bre da kantamo onu francusku pjesmu; opis susjede la vicina grande zize e lui oficial, ma vojno lice;

3. jezična i pjesnička kreativnost - o gradu Vodnjanu: aj vero si si anda na mater, o psu: a baštardin je laja zad hiže/ma ne se boj, ne griže samo liže, u Pulu je prokljeti vitar nanesa svi ti narod che non finisce mai, opis ulice la strada del mare je počivala u hladu, ili pak:

un piccolo Slovenac - dite

je suka mudante i stija činiti cagolu,

u parku, na oči svih, svih, svih!

i dragi očka ga je vidiu i popizdiu.18

Jezična je interferencija (te s njom kompatibilna glazbena raznorodnost i "nesređenost") bila svakako jedan od glavnih stilema u radovima grupe u prvih desetak godina rada ali i nakon toga, odišući šarenilom koje na svjetskoj glazbenoj sceni prepoznajemo u radovima umjetnika kao to su Frank Zappa ili Captain Beefheart.

\section{Tematika}

\subsection{Povijest Pule}

Ozračen poviješću, Blaškovićev je Gori Ussi pretresao gotovo sve što se umjetnički moglo obraditi i opjevati u povijesti Pule i Istre. Nakon očekivanih tema, kao što su položaj Istre u Italiji i Jugoslaviji, Drugi svjetski rat, fašizam, Austro-Ugarska i Mletačka Republika, Blašković je krenuo još dublje u prošlost, često u partikularno, posvećujući tako na albumima Kobra je u brajdi i /s-tri-janci pjesme velikanima kao i gubitnicima koji su se dotakli poluotoka ("spasitelj" pulskog Amfiteatra Gabriele Emo ${ }^{19}$, svećenik Jožef Velikanja20, Janko Vuković Podkapelski, Ivan Cankar, James Joyce, iredentist Nazario Sauro, socijalistica Giuseppina Martinuzzi, balerina Carlotta Grisi, izumitelj propelera Josef Ressel, carica Sissi, pa sve do antičke povijesti koja nas je dočekala sa svojim ostacima: Kažnjavanje Dirke, histarski kralj Epulon, sveti Jeronim, Agripina). Svim je individualcima iz te alternativne istarske povijesti zajednička dosljednost kojom grade, pišu, ratuju

\footnotetext{
17 "Ako pogledamo jezik koji koriste pulska djeca (u tal. školama, op.a.), nailazimo na mnoge elemente pidginizacije koji su vidljivi u siromaštvu rječnika, morfosintaktičkim pojednostavljenjima, siromašnim jezičnim vezama i konstantnoj upotrebi hrvatskih konstrukcija."; Gabriella Covri: La percezione della televisione: un'analisi comparata, u Percorsi didattici, br.3, Unione Italiana - Fiume i Università popolare di Trieste, Firenze-Trieste, 2003.

18 Pjesma Trst je naš, album Mens sana in malvasia istriana, 1990.

19 Gabriele Emo, mletački senator iz 16. stoljeća koji je spriječio da se pulski Amfiteatar demontira i prenese u Veneciju.

20 Jožef Velikanja (Srednja Kanomlja kraj Idrije, 1843. - Idrija, 1921.), "hajdučki pop", svećenik i narodni preporoditelj.
} 
ili plešu te povijest koja in često (ali ne uvijek) poražava poput neke mitske zvijeri. Posebno je dirljiva posveta Giuseppini Martinuzzi²1 u pjesmi Giuseppina ti voglio bene, u kojoj Blašković pjeva o osjećaju gubitka i nesigurnosti koji je prisutan danas u Istri i Hrvatskoj, žali nad sudbinom koja in je oboje zadesila (dimenticati dal buon pastore). Autor pjesme je Drago Orlić, dugogodišnji Blaškovićev suradnik, a pjesma je iste godine objavljena i u knjižnom izdanju. ${ }^{22}$ Negdje kada u pjesmi Blašković vikne La lotta continua, Pina combatti! Giuseppina postaje simbol neumrlog duha borbe za socijalnu pravdu.

Antipod toj pjesmi na ideološkom planu bila bi pjesma Ceš meza brata, Maria Pasquinelli?, koju je Blašković uglazbio na stihove Milana Rakovca i koja pripovijeda dogodovštine Marie Pasquine\|li, gorljive fašistkinje koja je 10. veljače 1947. ubila komandanta britanskog garnizona Roberta (ili Robina) W. De Wintona kao čin protesta zbog pripajanja Istre Jugoslaviji. Saveznički Vojni sud osudio ju je na smrt, kasnije je kazna zamijenjena doživotnom robijom, da bi 1964. bila amnestirana. Milan Rakovac piše pismo atentatorici i kroz više strofa polako meditira nekakvu vrstu pomirbe i prihvaćanja talijanske iredentistice. Otuda i naslov pjesme. Tako je naziva sestrom koju štima (cijeni), ali ona je i hudoba latinska i neoiredentista, i to u istom stihu, što vjerojatno i Blaškoviću kao izvođaču odgovara. Glazba je čisti rock bez primjesa, dapače, s veselim refrenom koji podsjeća i na She Loves You i Beatlese.

Između ta dva pola, oba ljudska i oba poražena kroz povijest, stoji povijest malih ljudi i njihovih patnji, koja je, paradoksalno, uspješno prikazana i u sudbini "velikih": carice Sissi i Franje Josipa. I tako, kada Franjo Josip postavlja spomenik svojoj voljenoj (već pokojnoj) Sissi, na trenutak sliči na starog istarskog udovca koji pokapa svoju ženu:

uona je volila Krf

ma Frane je pensa po svoju

ča je pusti otok kontra poluotoka ča je pusti Krf kontra Istre

(...)

spomenik je postavija na najjebenije moguće misto

spod Rene

kadi su spomeniki rivali jeni druge kako da su živi,

kako da su governi

a ne kusi grote i late ${ }^{23}$

Kao i još mnogo puta u dvadesetom stoljeću, povijest će se uplesti u raspored spomenika pod Arenom pa će i onaj carice Sissi dočekati izgnanstvo i uništenje. Pjesma je na čakavskom, pa su i imena povijesnih ličnosti pisana onako kako ih je narod nazivao: Franjo Josip zapravo Franc Jožef ili čak Frane, Sissi ima samo jedno s, što zabavlja slušatelja, daje mu osjećaj prisnosti s povijesnim likom i približuje ih čakavskom arealu. 


\subsection{Kritika sistema: antikapitalizam, antiklerikalizam}

lako su i prije 1990. godine tekstovi grupe ukazivali na nelogičnosti života u socijalističkom uređenju, dolaskom demokracije, i nelogičnosti liberalnog kapitalizma i nacionalizma, Blaškovićevo ogorčenje prerasta od kritike do pravih glazbenih napada na sve što je novi prokljeti vitar donio na ove prostore. Sam piše te ljute tekstove, u kojima na primjer opisuje napad na nekog nesretnika kojem je greškom pobjegla ekavica na splitskoj tržnici:

dobro... čovik, čovek je vjerojatno bija Srbin

to bi sigurno bija adut obrane, ali ej bre

mi smo na mrkatu - 1997. lita

a on je mršava stara sirota ki je sigurno

sam sebi kleja mater i porijeklo svoje i tuje

i prokleti bratski turbo ekspres lonac

u ken nisi moga nego najebati.

Mene je bilo sram - ne po hrvatski nego po ljudski24

Događaj ga je, čini se, toliko pogodio da je jedno vrijeme redovito izvodio tu pjesmu uživo (s odgovarajućim besidarskim uvodom prije same pjesme). Uz to, Blašković napada Big Brother (jedan je album nazvao Big Bljak), ogorčen je na ponašanje Katoličke crkve u novoj konfiguraciji moći (albumi Nek se širi vira Isusova i kasnije Božićna porno pastorala majke Crikve), napada IDS koji naručuje masterplan za razvoj Istarske županije pa jedan svoj album naziva album Masterplan, razočaran prodajom Istre i Istrijana kapitalu snima Istra kurcomanka, dok količina žuči i psovki u pjesmama raste... Svoje je razočaranje IDS-om ovako objasnio u Novom listu:

Nije do toga došlo odjednom. Skupljalo se to nezadovoljstvo u meni malo po malo. Skupljalo, skupljalo i puklo. Tada sam javno u "Glasu Istre" priznao da sam popušio svoje ideale. Istrijanstvo me nikako ne određuje. Ja sam samo ovisnik tog prostora življenja. To je ono što me određuje. Ali "tutto il mondo è paese", cijeli svijet je isti, cijeli svijet je jedno selo, jedino što se ja u Istri bolje osjećam, prijatnije mi je i to je sve. Istra je jako gostoljubiva ili zbog toga se pojavio konobarski sindrom. Paket servilnosti. Istra je kao i svaka druga regija. Nema neke posebne razlike od drugih regija, samo je svi mi u Istri idealiziramo. No, nismo mi jedini. Tako rade i Dalmatinci i Zagorci i svi ostali sa svojim regijama. ${ }^{25}$

Blaškovića je pogodila priča o radniku koji je nakon posla, obučen u trliš (radno odijelo) došao popiti kavu u neki lokal te je izbačen zbog svoje odjeće. To je postala jedna od nosivih pjesama albuma Masterplan, pokazatelj kamo nas vodi kapitalizam.

Šljaker u trlišu je doša u elit kafe, konobar, kafe koreto, brzo, hitro (je)

- šefe, šefe evo ga, još jedan kreten pešta jaja našim elitnim gostima

- brzo, brzo crleni telefon, zovi župana, biskupa, načelnika policije i direktora turističke zajednice

(...) Van š njin, van š njin, van š njin, nećemo ga tu!26

I dok su drugi bili još skloni zatvoriti oko na nezgrapnosti u IDS-ovoj fasadi, Blašković je krenuo s napadom, posebno na Ivana Jakovčića: 
Pa upravo je on izgovorio najgluplju stvar koja vrlo slikovito prikazuje njegov cinično-tehnokratski um, iako se on želi prikazati u sasvim drukčijem svjetlu. Kad je svojim glasačima tumačio svoje vizije budućnosti, kako on voli reći "za nas", jer on sve što radi, radi samo za nas, on je tamo samo za nas i radi nas. Je, on je Isus Krist. Pa je tako rekao: "Bolje biti čistačica u hotelu s pet zvjezdica nego s dvije zvjezdice". 27

Tako ljut, bisan kai brek, ostao je i nakon raspuštanja grupe, opet sanjajući neko bolje jučer (ovaj put samoupravni socijalizam) i na svom već sedamdeset šestom albumu - sedamnaestom od raspada - Fly me to the Marx iz 2010. godine.

\section{Zaključak}

lako i dalje piše, snima i objavljuje, rad Francija Blaškovića promijenio je s godinama oblik i intenzitet. Prestanak nastupanja dijelom je zamijenjen hiperprodukcijom, a rockerska pompoznost gotovo isposničkim pristupom radu. Promatramo tako povlačenje i zatvaranje umjetnika pred svijetom koji ga odbija i koji naziva big bljak, umjetnika koji odustaje od svojeg imena, od svojeg medija - koncerta - preko kojeg je komunicirao s publikom, od medija informiranja - novina i televizije, te od svojeg žanra (izjava za medije Ne pripadam površnosti amorala, u Glasu Istre) odričući se pedofilraja zvanog rock and roll.28 Jezične interferencije, dijalektalnost i višejezičnost, povijesne i političke teme, antiklerikalizam i ironija učinile su ga zanimljivijim od mnogih njegovih kolega, vrativši mu u kultnom statusu i kritičarskim priznanjima ono što je možda izgubio kod šire publike, nagradivši tako u konačnici njegov rad i upornost. 


\section{POPIS LITERATURE I IZVORA}

BENJAK - POŽGAJ HADŽI 2010

Mirjana Benjak, Vesna Pozgaj Hadži, "Od multikulturalizma ka interkulturalizmu", u Zbornik radova (Knjiga 1), Peti međunarodni interdisciplinarni simpozijum Susret kultura, Novi Sad, 2010, str. 163-172.

\section{BOBANOVIĆ 2002}

Paula Bobanović, Franci Blašković najveći zagovornik istrijanstva protiv IDS-a, Nacional 24. prosinca 2002.

\section{BOGLIUN-DEBELJUH 1990}

Loredana Bogliun-Debeljuh, Addio Pola Cosulich Patrizia, Istranova, br. 3., studenoga 1990.

\section{COVRI 2003}

Gabriella Covri, "La percezione della televisione: un'analisi comparata", u Percorsi didattici, br. 3, Unione Italiana - Fiume i Università popolare di Trieste, Firenze-Trieste, 2003.

JURKAS 2010

Anđelo Jurkas, Bez rocka trajanja, Znanje, Zagreb 2010.

\section{NAČINOVIĆ 1990}

Daniel Načinović, Čovik na tin svitu, Libar od Grozda, Čakavski sabor, Pula 1990.

\section{GROMAČA 2006}

Tatjana Gromača, Franci pljunuo istini u oči, Feral, 4. siječnja 2006.

\section{GRUPA AUTORA 2005}

Istarska enciklopedija, Leksikografski zavod Miroslav Krleža, Zagreb 2005.

\section{ORLIĆ 1998}

Franci Blašković, Đanino Božić, Drago Orlić, Nadan Rojnić, Daž daždi miš prdi, Errata corrige, Poreč 1998.

\section{ORLIĆ 2005}

Franci Blašković, Drago Orlić, Is*tri*janci, Errata corrige, Poreč 2005.

\section{ORLIĆ 2010}

Franci Blašković, Drago Orlić, Renato Percan, Nadan Rojnić, Re-cik-laža, Errata corrige, Poreč 2010 .

\section{MARKOVIĆ 2006}

Irena Marković, "I| code-switching tra istroveneto e cicacavo istriano nei testi di Franci Blašković", u Atti del XVII Congresso A.I.P.I., Asoli Piceno 2006

\section{ORLIĆ 1999}

Drago Orlić, Med i Teran, POU Poreč i Errata corrige, Poreč 1999.

\section{ORLIĆ 2004}

Ivona Orlić, Suvremeni istarski identitet: Besidarenje Francija Blaškovića i njegov doprinos konstrukciji identiteta Istrijana, Narodna umjetnost, 41/2, Zagreb 2004.

\section{ORLIĆ 2005}

Ivona Orlić, Suvremeni istarski identitet: Besidarenje Francija Blaškovića i njegov doprinos konstrukciji identiteta Istrijana, neobjavljeni magistarski rukopis

\section{TIDIĆ 2008}

Tidić, Tea: Ne pripadam površnosti amorala, Glas Istre, 28. veljače 2008.

\section{TIDIĆ 2008B}

Tidić, Tea: Udri jače, manijače!, Glas Istre, 5. ožujka 2008. 


\section{FRANCI BLAŠKOVIĆ E I GORI USSI WINNETOU - IL SUONO DELL'ISTRIA ATTRAVERSO LA PAROLA ISTRIANA}

Con il suo gruppo Gori Ussi Winnetou, Franci Blasković ha registrato 59 album dal 1986 al 2008, alternando molti collaboratori, autori e musicisti e sperimentando molti stili musicali. Nel lavoro vengono analizzati gli elementi costitutivi della sua produzione artistica quali le frasi idiomatiche, i temi storici e una critica del sistema politico-sociale. Blašković usa spesso il monologo (cantato e parlato) dove sono evidenti le interferenze linguistiche, il multilinguismo e il dialetto, mostrando talvolta l'influenza della canzone italiana.

Parole chiave: poesia dialettale, interferenza linguistica, rock and roll, storia di Pola 